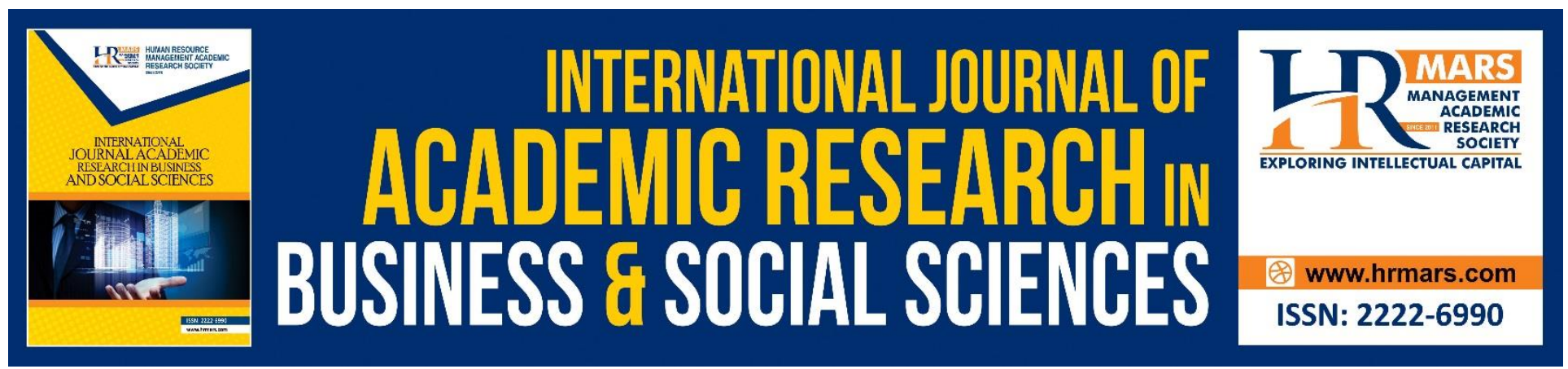

\title{
Gender and Job Preference of Accounting Graduates in Nigeria: A Conceptual Approach
}

\author{
Otakefe, Joseph Power, Ohidoa, Toluwa
}

To Link this Article: http://dx.doi.org/10.6007/IJARBSS/v9-i6/5980

DOI: $10.6007 /$ IJARBSS/v9-i6/5980

Received: 15 April 2019, Revised: 21 May 2019, Accepted: 04 June 2019

Published Online: 29 June 2019

In-Text Citation: (Otakefe \& Ohidoa, 2019)

To Cite this Article: Otakefe, J. P., \& Ohidoa, T. (2019). Gender and Job Preference of Accounting Graduates in Nigeria: A Conceptual Approach. International Journal of Academic Research in Business and Social Sciences, 9(6), 664-672.

\section{Copyright: (C) 2019 The Author(s)}

Published by Human Resource Management Academic Research Society (www.hrmars.com)

This article is published under the Creative Commons Attribution (CC BY 4.0) license. Anyone may reproduce, distribute, translate and create derivative works of this article (for both commercial and non-commercial purposes), subject to full attribution to the original publication and authors. The full terms of this license may be seen

at: http://creativecommons.org/licences/by/4.0/legalcode

Vol. 9, No. 6, 2019, Pg. 664 - 672

http://hrmars.com/index.php/pages/detail/IJARBSS

JOURNAL HOMEPAGE

Full Terms \& Conditions of access and use can be found at http://hrmars.com/index.php/pages/detail/publication-ethics 


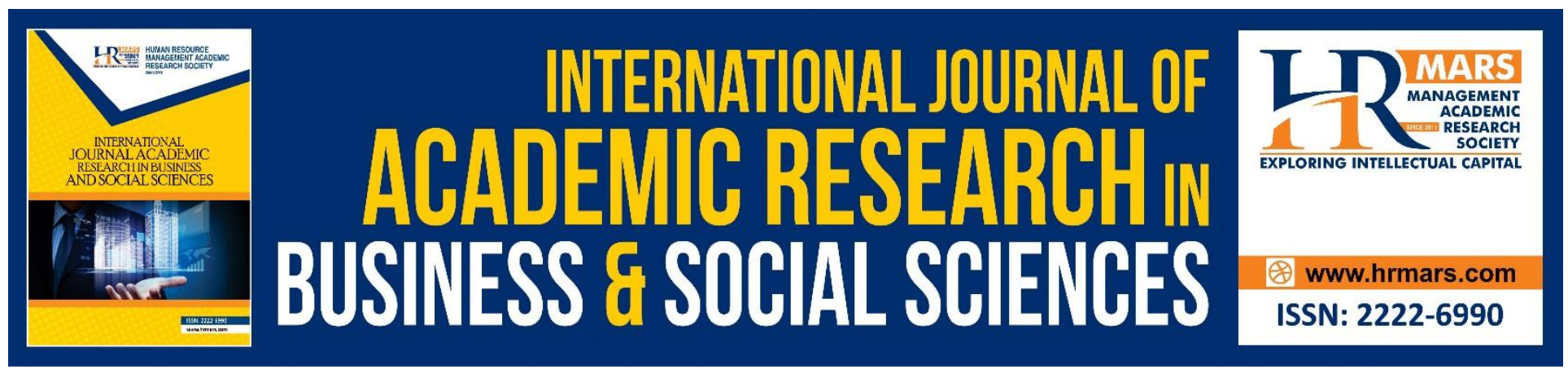

\title{
Gender and Job Preference of Accounting Graduates in Nigeria: A Conceptual Approach
}

\author{
Otakefe, Joseph Power, Ohidoa, Toluwa \\ Accounting Department, University of Benin, Benin City, Edo State, Nigeria \\ Email: evetolambassador@gmail.com
}

\begin{abstract}
The broad objective of this study was to examine gender as determinant of job preference among accounting graduates in Nigeria. The library research method was employed. Literatures were reviewed on this gender. It was discovered that though this study focused on accounting graduates in Nigeria, it can be used as a basis for measuring the thinking and aspirations of graduates from other disciplines.
\end{abstract}

Keywords: Accounting, Accounting Graduate, Determinants, Gender, Preference

\section{Introduction}

Choice or preference is predicated on the availability or existence of alternatives to a product or service in the market. Thus, where there are no alternatives to a particular product or service, the question of choice or preference may not be necessary, in which case an individual may just pick or accept what is available bearing in mind his ability to pay. It is the availability of the range of products or services, together with ability to pay that empowers individual preference or choice power (Otakefe, 2015).

The accounting profession or discipline as it were, offers accounting graduates several job prospects or opportunities. For instance, job prospect or opportunity for an accounting graduate include: teaching, working in the industry, working in the public sector, working in the private sector, working in practicing firms (auditing firm) or self-employment. Even within the teaching choice, the graduate accountant could exercise preference either to teach book keeping and accounts in secondary school or lecture in College of Education or Polytechnic or even the University. If he decides to work in the industry, he may have to make choice of which industry to pick up the job. Similarly, if his choice is to work in the public sector, he may decide to make choice on whether to work with the Federal, State or Local Government. Also, if his choice is to work in an audit firm, a range of alternative is also available for him to exercise his preference such as audit and assurance service, tax service or other non-audit service which an accounting firm can render (Otakefe, 2015).

Human beings are different in exercising their choice or preference. Such preference could be affected by certain factors which may range from age, gender, peer group influence, economic 
reasons, social reasons, type of education, the school attended or even reference. Therefore, understanding why accounting graduates prefer one job offer over another is very important. This is because one of the challenges facing the accounting profession is the recruitment and retention of high quality personnel (Bloom \& Myring, 2008). In recent years, the demand for accounting graduates has been strong. Competition for the "best and the brightest" accounting graduates is intense, particularly among large public accounting firms, which experience high turnover rates as talented employees leave for lucrative and less stressful positions in private industry. Although a severe economic downturn beginning in the fall of 2008 lessened the demand for accounting graduates, the employment outlook for entry-level accountants overall is positive (Bloom \& Myring, 2008).

In the Nigerian situation, one of the major causes of unemployment has been the rapid growth in the enrolment rate of students at all levels of our educational system, especially with the introduction of the Universal Primary Education (UPE) which was launched on the $6^{\text {th }}$ day of September, 1976 during the regime of General Olusegun Obasanjo (Okoye \& Otakefe, 2003). In addition to the above factor that quite a sizeable number of primary and secondary school leavers usually graduate with minimal usable skills that will enable them to secure jobs in the labour market. The problem therefore is not so much of the production of school leavers as it is the production of persons with little or no irrelevant skills.

The worldwide economic depression of the early 80 's caused a rapid deterioration in Nigeria's economy. Industrial output shrank to an all time low level and commercial activities were consequently reduced, leading to the loss of employment opportunity for millions of Nigerians. By the end of 1985, the unemployment situation in Nigeria has reached desperate and alarming proportions. The adverse effect and direct result was an urban employment of over ten percent (10\%) of youths under the age of thirty (30) years. The resultant outcome of the aforementioned factor was a general despondency in youths and parents (Okoye \& Otakefe, 2003). Therefore, the motivation of this research is to study the issues relating to the determinants of job preference of accounting graduates. The purpose of this study is to conceptually assess the relative importance of individual characteristics as a factor affecting accounting graduates' employment choices in Nigeria.

\section{Gender and Job Preference of Accounting Graduates}

The job preference of any individual is affected by many factors. These factors depend on the individual's interests and the circumstances which surround the individual as regards the determination to prefer a particular job to another. These factors have, at one time or the other, been found to have a great influence on the desire of individuals in taking to certain professions. This is not strange as other human endeavours have various motivating factors which influence those who seek to go into them.

Gurin and Katz (1966) studied factors affecting occupational aspiration of graduating students in ten Southern black institutions in America and found that the males showed positive relationship between their fathers' occupation and both the prestige and ability dimension. The effect of their mothers' occupation and education were also seen. According to them, "a family where the mother is highly educated precipitates and encourages the choosing of occupations that are prestigious or with demanding ability." They further found that girls whose mothers had some college education chose occupations which were less demanding of ability than girls whose mothers had a little higher 
school education. Based on the above argument raised by Gurin and Katz, it is seen that parental occupation and educational background influenced their children's academic pursuit and subsequent job preference. Gracey (1977) observed that their fathers' occupation and educational expectation exerted a greater influence on the male children's level of aspiration and choice of jobs while their mothers' own exerted a high influence on the level of aspiration and choice of occupations of females. The reason for this is somehow psychological. One might explain this by the fact that children hold a strong role identification with parents of the same gender.

Another factor which has continued to receive much attention as a motivating factor for the choice of an occupation and a career is the gender of an individual and the family identification of the parents. A close look at the history of traditional education in Nigeria reveals how gender was a determinant of the choice of a career, hence males usually took to the job or whichever profession their fathers belonged to while the females occupied themselves with home management, helping their mothers to take care of the home and the young ones. Dowell (1980: $49-64)$ referred to the above argument as "sex differentiation in occupation".

Thomas (1978), on the other hand, was also of the opinion that gender influences the choice of an occupation and a career. Based on the above, the job preferences of accounting graduates in Nigeria might have been influenced, to a large extent, by gender factor.

Okediji (1973) observed that women settle for certain jobs like nursing and teaching because the two professions are largely associated with women and because they think they would lose their feminity if they aspire to go into too demanding occupations. He went further to cite the work of Gurin and Katz (1966) which stated that women prefer occupations that are less demanding of physical exertion.

Again, a large body of research indicates that gender has a significant influence on job preference. Kochanek and Norgaard $(1984 a, b)$ requested a group of accounting graduates who had accepted jobs or who had offers they planned to accept to rank the factors which had most significantly influenced their decisions. Women ranked as most important firms' personnel, followed by firms' location and opportunities for advancement. Men also ranked firms' personnel as the most important criterion, but reversed the ranking for the other two factors.

Reed and Kratchman (1989) distributed a list of 35 job attributes to a sample of senior accounting majors. The subjects were asked to rate the importance of these attributes. The researchers concluded that women were more interested than men were in jobs which permit personal growth and require little travel or overtime, while men preferred jobs that allow them to exercise leadership qualities and use originality.

In a similar study, Lathan, ostrowski, Pavlock, and Zeott (1987) implored graduate accounting majors to rank 12 quantitatively selected attributes of potential employers. The researchers identified promotion opportunities and prospects for high future earnings as factors more important to male job seekers. The same study found that females were more interested in warm, friendly personnel, continuing professional development, location, fringe benefits, starting salary, amount of travel and overtime required.

Manhardt (1972) provided a positive explanation for the gender-related differences found in the above studies. After analysing data from a five-year study of college graduates, he discovered that men rated characteristics contained in an advancement and responsibility factor higher, while 
INTERNATIONAL JOURNAL OF ACADEMIC RESEARCH IN BUSINESS AND SOCIAL SCIENCES Vol. 9, No. 6, June, 2019, E-ISSN: 2222-6990 @ 2019 HRMARS

women gave higher ratings to characteristics contained in a work environment factor. Manhardt concluded that a significant proportion of women do not regard a job and a career as a significant factor in their lives and thus are more concerned with job selection factors relating to work environment than to long-term career success.

Other studies have explored the relationship between individual characteristics such as gender, marital status, and grade point average and the career choices of accounting graduates. Shivaswamy and Hanks (1986) conducted a survey of accounting graduates and found that the males in the sample expressed more of an interest in public accounting than did the females. They found that graduates with higher GPAs and students closest to graduation ranked public accounting ahead of industrial/commercial accounting, while graduates with lower GPAs and those farthest from the job market reversed the rankings. The differences in the mean scores of married and single graduates were not statistically significant.

Danziger and Eden (2007) examined relevant gender differences in occupational aspirations when considering job preferences of graduates with similar abilities who studied competitively in the same achievement-oriented educational setting. The findings revealed that in their first year, the sexes shared a similar pattern of aspirations and goals. However, during their later academic years, females reduced their occupational aspirations and revealed a stronger preference for a convenient balance between work and other facets of life. The study finally demonstrates that there is a statistically significant effect of the interaction between gender and academic year on graduates' occupational aspirations and job preferences.

The work of Sloane and Ward (2001) showed that the significant gender differential in overall job choice and satisfaction is substantially confounded by cohort effects. Indeed, it appears that while male graduates are more satisfied than their female counterparts in terms of salaries, the females prefer leisure. Stevens (2005), while examining the determinants of UK academics' perceived satisfaction of several job domains as well as the effect of pecuniary and non-pecuniary job facets on the intention to quit the university, found that both aspects of the job were significant prediction of the likelihood of graduates' choice of job preferences. Sobharwal and Corley (2009) examined gender disparities in job choice and job satisfaction across disciplines and discovered that male graduates are significantly less satisfied than their female counterparts when it comes to working in the public sector.

Male and female college students have marked differentiated distributions across fields of study: men are disproportionally more present in engineering, mathematics/science and business, while women more often opt for majors like education, humanities and social sciences. In most countries, the former fields lead to well remunerated occupations like scientists, professional and high-ranked technicians, while the latter usually lead to less remunerative jobs like teaching, social work, or jobs in cultural or non-profit organizations (Gerber \& Cheung, 2008). These findings are the result of two tendencies: a less uneven distribution of fields of study according to sex and trends in gender-specific returns.

Some studies found that occupations are highly segregated by sex and that the degree of gender segregation is stronger at lower levels of education and occupation. This is because women's integration occurs more in professional and managerial jobs than in clerical and blue-collar occupations (Cotter et al., 2004). Nevertheless, among graduates, men are overrepresented in upper 
management and in the most prestigious professions (engineers, academic professors), whereas women dominate in professions like nursing and teaching (England, 2005). Even if some differences across countries are recognizable, the overall pattern of occupational segregation by sex is rather similar in most of economically advanced countries (Charles \& Grusk, 2004).

Feminist literature stresses that motherhood could also be a relevant factor because it needs retirement from work for a certain period of time and this is costly for employers. If this explanation holds, ceteris paribus, employers would prefer men to women for jobs that require more on-the-job training in order to minimize the risk of losing a worker. Studies show the existence of differences between males and females in preferences, aspirations and general life purposes. There is evidence that men tend to attribute more importance to occupational career and income, whereas women attribute a higher value to non-job aspects like family realization (Marini et al., 1996; Halaby, 2003). Thus, women's occupational aspirations are lower than those of men and, in the choice of jobs; they seem to consider important aspects other than income like security and flexibility employment (Croson \& Gneezy, 2009). According to social researhers, these differential preferences and aspirations derive from gender-typed processes of socialization and informal peer pressure, but prior studies in the evolutionary psychology domain suggest the existence of biological differences between men and women in the desire to earn money (Kanazawa, 2005).

\section{Theoretical Framework}

This section of the study focuses on theoretical framework. The essential theories relevant for use in order to achieve the purpose of this study include value orientation and attribute theories. These two theories altogether provide solid underpinning for this study.

\section{Kluckhohn and Strodtbeck's Values Orientation Theory}

It is common knowledge that people's attitude are based on the relatively few stable values they hold. Kluckhohn and Strodtbeck (1961) proposed a theory called value orientation theory which states that every human society must answer a limited number of universal questions, that the valuebased solutions are limited in number and universally known, but that different cultures have different preferences among them. According to the theory, suggested questions could include human relations with time, nature and one another, as well as basic human motives and the nature of the human nature.

This theory has since been tested in many other cultures used to help negotiating ethnic groups understand one another, and to examine the inter-generational value changes caused by immigration. Examples of this were the studies undertaken by Hills $(1977,1980)$ and Lane $(1976)$ of changes in the disparity in values between young people and their parents as a result of migration. The result of their study showed that values are central to human thought, emotions and behaviours. They are cross-culturally relevant and valid, and allow both between-group comparisons. If we accept that values are important, then the Kluckhohn and Strodtbeck's theory of values orientation is a useful and valid framework for studying the job preferences of accounting graduates. 


\section{Attribution Theory}

Attribution theory has to do with people's causal explanations of events. According to Heider (1958), attribution theory is about how common sense operates or how the man or woman on the street explains events and the psychological and behavioural consequences of such explanations. Inspired by Heider's (1958) writings, social psychologists and researchers have become increasingly concerned with and interested in the processes by which people explain their own successes and failures (Weiner, 1995).

According to Heider's (1958) basic assumption, people have an innate need to understand and control their immediate environments; hence individuals develop causal explanations for significant events as they experience them. As Rotter (1996) posited, these beliefs about causality influence expectations which in turn could influence subsequent behaviour. These theorists are, therefore, more concerned with the perceived causes rather than the actual causes of events and consequences of those perceptions (Fostering, 2001). For instance, possible consequences that might occur in the current study are that an accounting graduate who has been influenced by a value system that places much emphasis on wealth or riches is more likely to opt for a job with a fat salary rather than job security or jobs with a high future career prospect.

\section{Conclusion and Recommendation}

Base on the outcome from this work, it is recommended that job preference factors such as fat starting salary, job security, challenging and interesting work, advancement potential, expected future salary and all other job preference factors observed in this work must be examined by both employers and all stakeholders in the formulation of policy decisions regarding human resource management. This is because youths form the buck of the labour force in any nation. Though this study focused on accounting graduates in Nigeria, it can be used as a basis for measuring the thinking and aspiration of graduates from other disciplines. Policy regulators can use the result of this study as a guide in the formulation of policies, particularly, those that have to do with youth employment and empowerment.

\section{References}

Bloom, R., \& Myring, M. (2008).Charting the future of the accounting profession.CPA Journal, 78(6), $65-67$.

Charles, M., \& Grusky, D. B. (2004).Occupational ghettos: The worldwide segregation of women and men. Standford (CA): Standford University Press.

Cotter, D. A., Hermsen, J. M., \&Vanneman, R. (2004).Gender inequality at work. New York: Russell Sage Foundation.

Croson, R., \& Gneezy, U. (2009).Gender differences in preferences.Journal of Economic Literature, $47(2), 448-474$.

Danziger, N., \& Eden, Y. (2007). Gender-related differences in the occupational aspirations and career-style preferences of accounting students: A cross-sectional comparison between academic schools years. Career Development International, 12(2), 129 - 149.

England, P. (2005). Gender inequality in labor markets: The role of motherhood and segregation. Social Policy, 12(2), $264-288$. 
INTERNATIONAL JOURNAL OF ACADEMIC RESEARCH IN BUSINESS AND SOCIAL SCIENCES

Vol. 9, No. 6, June, 2019, E-ISSN: 2222-6990 @ 2019 HRMARS

Gerber, T. P., \& Cheung, S. Y. (2008). Horizontal stratification in postsecondary education: Forms, explanations, and implications. Annual Review of Sociology, 34(1), $299-318$.

Gracey, J. S. (1977). Social, academic and personal factor in career aspiration of American female youths.Dissertation Abstracts International, XXXVII(V), p. 2429A.

Gurin, P., \& Katz, D. (1966). Motivation and aspiration in the negro college. Technical report 1966 University of Michigan Contact No.OE-4-10-095 United States Department of Education and Welfare Office of Education.

Harris, M. M., \& Fink, L. S. (1987). A field study of applicant reactions to employment opportunities: Does the recruiter make a difference? Personnel Psychology, 40, $765-784$.

Heider, F. (1958).The psychology of international relations. New York: Wiley.

Heider, F. (1958). The psychology of international relations. New York: Wiley.

Hills, M. D. (1977).Values in the South Pacific. Paper presented at the Annual Conference of the New Zealand Psychological Society, Aukland.

Hills, M. D. (1977).Values in the South Pacific. Paper presented at the Annual Conference of the New Zealand Psychological Society, Aukland.

Hills, M. D., \& Goneyali, E. (1980).Values in Fijian families.Monography published by Department of Psychology, University of Waikato, Hamilton.

Hills, M. D., \& Goneyali, E. (1980).Values in Fijian families.Monography published by Department of Psychology, University of Waikato, Hamilton.

Kanazawa, S. (2005). Is "discrimination" necessary to explain the sex gap in earnings? Journal of Economic Psychology, 26, 269 - 287.

Kirsch, R., Leathers, P. E., \& Snead, K. C. (1993).Student versus recruiter perceptions of the importance of staff auditor performance variables.Accounting Horizons, 7(4), $58-69$.

Kluckhohn, F. R., \& Strodtbeck, F. L. (1961).Variations in value orientations. Evanston, III: Row, Peterson.

Kochanek, R. F., \& Norgaard, C. T. (1985).Student perceptions of alternative accounting careers - Part 1.The CPA Journal, $36-43$.

Kochanek, R. F., \& Norgaard, C. T. (1985b, June). Student perceptions of alternative accounting careers - Part II.The CPA Journal, $26-32$.

Lane, R. H. (1976). Polynesia and Europe meet: A new heritage. M.Soc. Sci. Thesis, University of Waikato Psychology Department. Hamilton: University of Waikato.

Lathan, M. H., Ostrowski, B. A., Pavlock, E. J., Scott, R. A. (1987). Recruiting entry level staff: gender differences. The CPA Journal, $30-42$.

Manhardt, P. J. (1972). Job orientation of male and female college graduates in business. Personnel Psychology, 25, $361-368$.

Marini, M. M., Fan, P.-L., Finley, E., \&Beutel, A. M. (1996).Gender and job values.Social Educ., 69, 49 -65 .

McDowell, D. (1980). The impact of the national policy on education.International Review on Education, 26(1), $49-64$.

Okediji, P. A. (1973). Motivational, racial and socio-economic correlates of occupational aspiration. West African Journal of Education, 17(1). 
INTERNATIONAL JOURNAL OF ACADEMIC RESEARCH IN BUSINESS AND SOCIAL SCIENCES

Vol. 9, No. 6, June, 2019, E-ISSN: 2222-6990 @ 2019 HRMARS

Okoye, A. E., \& Otakefe, J. P. (2003). Career choice and employment preferences of students: A comparative analysis of education accounting students and accounting major students in Nigeria. The Nigerian Journal of Management Research, 3(1) (July/December).

Otakefe, J. P. (2015). Determinants of job preferences among accounting graduates in Nigeria. A Ph.D Dissertation (Unpublished).

Reed, S. A., \& Kratchman, S. H. (1989). A longitudinal and cross-sectional study of students' perceptions of the importance of job attributes. Journal of Accounting Education, 7, 172 193.

Rotter (1996).Generalised expectations for internal versus external control of reinforcement. Psychological Monographs, 80(609).

Sabharwal, M., \& Corley, E. A. (2009).Faculty job satisfaction across gender and discipline.The Social Science Journal, 46, $539-556$.

Shivaswamy, M. K., \& Hanks, G. F. (1986). Career preferences of accounting students: Are occupational choices restricted? Journal of Education for Business, $119-122$.

Sloane, P., \& Ward, M. (2001).Cohort effects and job satisfaction of academics.Applied Economics Letters, 8(12), $787-791$.

Stevens, P. (2005). The job satisfaction of English academics and their intentions to quit academe, NIESR discussion papers 262, National Institute of Economic and Social Research.

Thomas, L. C. (1978). A study of differences in self-concept, vocational preference and school achievement among black and white high school students.Dissertation Abstract International, $X X X I X(V)$, p. 2764A.

Turban, D. B., Eyring, A. E., \& Campion, J. E. (1993). Job attributes: Preferences compared with reasons for accepting and rejecting job offers. Journal of Occupational and Organizational Psychology, 66, $71-81$.

Weiner, T. (1995). An attribution theory of motivation and emotion: Applications of a naïve psychology. Journal of Social and Clinical Psychology, 5, $405-419$. 